\title{
Digital Currencies and the Future of Money
}

\author{
Hiromi Yamaoka
}

\section{The Modern Monetary System}

\subsection{Brief History of the Modern Monetary System}

Most countries now share an established model of providing money to the economy through a two-tiered structure, which consists of a central bank and commercial banks. Each country or jurisdiction has one central bank as a single issuer of its sovereign currencies, which are called central bank money. Commercial banks provide deposits that function as both payment instruments, referred to as commercial bank money, and the sources of their financial intermediation.

The modern monetary system was formed in the later stage of modern nation states. Although commercial banks were born in the late Renaissance era, modern central banks were established almost simultaneously in the nineteenth century (Maes, 2018). For example, the Reichsbank was formed in 1876 and the Bank of Japan in 1882. There are some central banks, such as Sveriges Riksbank and the Bank of England, which were founded in the seventeenth century. Nonetheless, these banks were originally akin to commercial banks, and became the single issuers of sovereign currencies in the nineteenth century. Indeed, the Bank of England became the single issuer of its sovereign currency in 1844 owing to the Peel Banking Act, and Sweden placed the power for issuing its sovereign currency in the Sveriges Riksbank in 1897.

The credibility of money is based on people's trust, and it was the establishment of modern nation states that could build sufficient trust in their sovereign currencies and central banks. There were various elements and institutional frameworks, such as legal systems, taxation powers, and banking regulations, that enabled the emergence of the modern monetary system (Yamaoka, 2019).

H. Yamaoka $(\varangle)$

Future Institute of Research, Tokyo, Japan

e-mail: h.yamaoka.7w@future.co.jp 


\subsection{Benefits and Advantages of the Modern Monetary System}

Although the history of modern central banking is brief, most countries came to have their central banks function as the single issuers of their sovereign currencies during the nineteenth and the twentieth centuries, and to use a two-tiered structure to organize the modern monetary system. This fact suggests that the system has been efficient and beneficial to the economy.

Indeed, the modern monetary system with its two-tiered structure has various advantages and benefits (Study Group on Digital Currency Settlement Infrastructure, 2020). First, both central bank money and private money are denominated by a single currency unit, and there is no additional cost or inefficiency stemming from the exchanges of payment instruments with different units. Cash, central bank deposits, commercial bank deposits and other private payment instruments are exchangeable with one another on a one-to-one basis. In order for this system to work smoothly, the credibility of bank deposits is secured by banking regulations, supervision, and deposit insurance.

If two or more currency units were to be used in a single jurisdiction, individuals and firms would need to verify the credibility of each currency unit and decide whether or not to accept it in each transaction. Moreover, they would have to bear the cost related to the exchange of currencies with different units. In this regard, the invention of the modern monetary system has significantly reduced costs and risks in the economy.

Second, the modern monetary system contributes to efficient resource allocation led by private-sector initiatives. Commercial banks can use deposits as the source of their loans and investments under the partial reserve system. As each bank tries to make loans and investments to projects with higher returns and lower risks, privatesector initiatives can be utilized to improve the allocation of resources.

Third, innovation led by private-sector initiatives can be encouraged. Indeed, private entities have created various instruments within the monetary systems such as checks, wire transfers, ATMs, credit cards, debit cards, and mobile payments were invented by private entities. Central banks have carefully avoided occupying the monetary infrastructure, letting private entities innovate their own payment and settlement services instead.

Fourth, data attached to payments and settlements can be utilized by private entities. Central banks issue two types of central bank money: cash and central bank deposits. Cash, which can be used by anyone for daily transactions, is anonymous and its ownership is unknown to central banks. Central bank deposits are used mainly by banks and for large-scale settlements. From the viewpoint of data utilization, central banks process data from large-scale interbank transactions, which is necessary for maintaining the stability of payment and settlement systems, while avoiding the monopolization of the data attached to daily transactions.

Over the past century, almost all nation states, including developed, emerging, and developing nations, have given their own central banks the exclusive responsibility 
of issuing sovereign currencies, ${ }^{1}$ which has led to a two-tiered monetary system, consisting of the central bank and commercial banks-a system that has proved effective in enhancing the efficiency of transactions and economic development. ${ }^{2}$

\section{Digital Innovation and Challenges to the Modern Monetary System}

\subsection{Digital Innovation and the Monetary System}

After the emergence of commercial banks, which coincided with the introduction of printing technology in the Renaissance era, payment infrastructures had mainly operated on paper-based technologies. Central banks issued paper-based banknotes and people used checks as payment instruments. In the twentieth century, electronics-based technologies fostered the development of new payment infrastructures including wire-transfers, ATMs, credit cards, and debit cards. Then, at the period of the global financial crisis in 2008, new digital technologies emerged almost simultaneously (Yamaoka, 2019).

The iPhone was born in 2007 and smartphones have been spreading worldwide ever since. According to a survey by the World Bank Group (2017), among a population of 1.7 billion adults without bank accounts, over 1.1 billion had mobile phones. The popularization of mobile phones and smartphones has drastically promoted financial inclusion worldwide by enabling people to access mobile payment services.

Bitcoin, the first crypto-asset, as well as blockchain and other distributed ledger technologies (DLTs) were introduced in 2009. Although bitcoin and other firstgeneration crypto-assets have not been used as payment instruments but as speculative investment targets, blockchain and other DLTs have become technological platforms for new payment infrastructures such as Libra.

Big data has become the core of various economic activities. The volume of data has drastically increased due to web-browsing, social networking service (SNS), e-commerce, and smartphone apps. Billions of smartphone users worldwide are producing gigantic amounts of data through SNS posting, web-browsing, and game playing. It is estimated that over $90 \%$ of the data produced in the history of humanity has been created in the last two years alone (SINTEF, 2013). Data are now regarded

\footnotetext{
${ }^{1}$ On the website of the Bank for International Settlements (BIS), 191 central banks were listed on April 1st, 2019, while there are 189 member countries in the International Monetary Fund.

${ }^{2}$ For example, the Committee on Payment and Settlement Systems of the Bank for International Settlements (2003, 1-2) stated as follows: "(C)entral bank and commercial bank money coexist in a modern economy $[\ldots]$ the composite of central and commercial bank money is an essential feature of the monetary system and should be preserved. [...] This policy position implies a rejection of the two extreme arrangements of monobanking, where the central bank acts as the sole issuer of money, and free banking, where commercial banks provide all the money required by the economy. Neither of these corner solutions has proven to be sufficiently stable or effective to endure."
} 
as the "new oil of the twenty-first century" (Lowe, 2021) and as useful intangible assets, they can create added value in multiple ways. AI and deep learning, which can be used as tools for analyzing big data, also started developing rapidly since around 2010.

Backed up by these technological advances, a new industrial movement has emerged: Fintech, that is, the application of new information technologies to financial services such as smartphones, AI, blockchain, and other DLTs (International Monetary Fund and World Bank, 2019). Big data and these technologies have facilitated the growth of Big Tech firms worldwide. Many new entities, including start-ups and Big Tech firms, are now entering into financial businesses. Fintech has promoted financial inclusion, since more and more people in emerging and developing countries now have access to payment services through their smartphones.

\subsection{New Challenges to the Modern Monetary System}

Digital innovation has brought about various new challenges to the modern monetary system.

\section{Crypto-Assets (Virtual Currencies)}

Bitcoin and other first-generation crypto-assets are inherently outside the scope of nation states. They are not denominated by sovereign currency units. Bitcoin tries to build trust and credibility, which are prerequisites for money, through computing power and not through the credibility of nation states. If these first-generation cryptoassets are widely used in domestic transactions, the effectiveness of macro-policies, including monetary policy, will be reduced substantially. Since traditional monetary policy influences only the supply and interest rates of sovereign currencies, it would not affect economic activities undertaken in crypto-assets.

So far, first-generation crypto-assets have rarely been used as payment instruments. Instead, they have remained speculative investment targets. This fact implies that the cost of creating trust and credibility beyond the framework of nation states could be high, as illustrated by, for example, the massive consumption of electricity required for their operation. Thus, the impact of first-generation crypto-assets on the effectiveness of macro-policies has so far been limited. Nonetheless, crypto-assets have paved the way for new payment instruments such as Libra.

\section{Big Tech as Payment Service Providers}

Under the recent data revolution, Big Tech firms, such as GAFA (Google, Amazon, Facebook, and Apple) in the United States and BAT (Baidu, Alibaba, and Tencent) in China, have been growing very rapidly. These Big Tech firms have grown to become 
the top companies in the world in terms of market capitalization, and their economic power surpasses that of several countries.

Although data is often called the "oil of the twenty-first century," there are several differences between oil and data (Haldane, 2018; Yamaoka, 2019): First, data does not depreciate after being used. Second, data does not need much space for its storage. Third, the marginal utility of data could increase as the volume of data increases. Accordingly, data may have the tendency to be concentrated. Although the origins of Big Tech firms vary, they are similar in terms of accumulating gigantic amounts of data and utilizing it for a variety of businesses.

These Big Tech firms have recently entered into payment services. Among them, Alipay of Alibaba group and WeChat Pay of Tencent group have become the biggest payment networks in terms of the number of users. Tencent launched WeChat Pay in 2013, and it now has around 1 billion users.

The entry of Big Tech firms into payment services challenges modern monetary systems in a couple of aspects (Yamaoka, 2019). First, non-banks are becoming big players in payment infrastructures. Indeed, several central banks have recently allowed non-bank payment service providers to have central bank accounts. In China, Alipay and WeChat Pay have been required to deposit the amount equivalent to their customer balances at central bank accounts. These developments challenge the twotiered structure consisting of a central bank and commercial banks. Second, payment infrastructures operated by these Big Tech firms tend to be gigantic and challenge the authorities' power to control payment systems.

\section{Libra Led by Facebook}

In June 2019, the plan of Libra, a digital currency led by Facebook, was announced and gathered great attention (Diem Association, 2020).

Bitcoin and other first-generation crypto-assets are not used as payment instruments because of their high volatility and insufficient number of users to generate network externalities necessary for payment instruments to be used. In this regard, Libra planned to be fully backed up by safe assets denominated by highly credible sovereign currencies such as the USD and EUR in order to stabilize its value. Moreover, Facebook already has over 2 billion users worldwide, so Libra could have sufficient network externality if issued. In other words, Libra tried to overcome the defects of first-generation crypto-assets in order to be used as money.

In general, the global regulatory community was cautious about the Libra project. In April 2020, Libra modified its plan and in December 2020 changed its name into Diem. Libra has not yet been issued although it was originally planned to be issued in the first half of 2020. Nonetheless, the Libra project seemed to have accelerated studies of central bank digital currencies. 
Table 1 Classification of digital money

\begin{tabular}{|c|c|c|c|}
\hline Issuer & Banks & $\begin{array}{c}\text { Non-bank } \\
\text { private entities }\end{array}$ & Central banks \\
\hline $\begin{array}{c}\text { Denominated in } \\
\text { sovereign currency } \\
\text { unit }\end{array}$ & $\begin{array}{c}\text { Bank deposits, Debit } \\
\text { cards, Swish, J-Coin } \\
\text { Pay, etc. }\end{array}$ & $\begin{array}{c}\text { E-money, M-Pesa, } \\
\text { Alipay, WeChat Pay, } \\
\text { etc. }\end{array}$ & $\begin{array}{c}\text { Central bank digital } \\
\text { currencies } \\
\text { (CBDCs) }\end{array}$ \\
\hline $\begin{array}{c}\text { Not denominated in } \\
\text { sovereign currency } \\
\text { unit }\end{array}$ & $\begin{array}{c}\text { Crypto-assets } \\
\text { (virtual currencies) }\end{array}$ & \\
\hline
\end{tabular}

Source by the author.

Table 2 Two types of CBDCs

\begin{tabular}{|l|l|}
\hline \multicolumn{1}{|c|}{ Central Bank Money (Base Money) } & \multicolumn{1}{c|}{ CBDCs } \\
\hline Banknotes & $\rightarrow$ General-purpose CBDCs \\
\hline Central Bank Deposits & Large-value CBDCs \\
\hline
\end{tabular}

Source by the author.

\subsection{Central Bank Digital Currencies ${ }^{3}$}

\section{Basic Concept}

Central bank digital currencies (CBDCs) are characterized as digital payment instruments denominated by sovereign currency units and issued as central bank liabilities of central banks (Table 1).

Central banks issue two types of central bank money, which are banknotes and central bank deposits. Banknotes can be used by anyone at any time for daily transactions, and central bank deposits are used for large-value transactions mainly by banks. In parallel with these two categories, central bank digital currencies can also be classified into two types (Table 2). The first category is general-purpose CBDCs, which share characteristics with banknotes and are used by wide-ranging entities including individuals. The second category is large-value CBDCs, which share characteristics with central bank deposits and are used for large-value settlements mainly by banks.

Central banks in developed countries in general started studies on large-value CBDCs. Since central bank deposits have already been digitalized, large-value CBDCs are unlikely to cause issues related to financial stability or monetary policy. In other words, large-value CBDCs could be understood as applying DLTs like blockchain to already-digitalized central bank deposits. The European Central Bank (ECB) and the Bank of Japan started their joint research entitled Project Stella in 2016 (Bank of Japan, 2016). There have been many other projects including Project

\footnotetext{
${ }^{3}$ See also the chapter by Bindseil in this volume.
} 
Table 3 Several issues with CBDCs

Impacts on bank deposits?

- Deposits $\Rightarrow$ CBDC? (decrease in bank loans?)

- Digital bank run?

- Deposits $\Rightarrow$ CBDC as "flight to safety," accelerating liquidity crisis?

Zero lower bound?

- CBDC might be used for avoiding negative interest rates on reserves

- Interest-bearing?

- Positive rate on CBDC might accelerate the decline in bank deposits

- Negative rate on CBDC might deteriorate consumer sentiments

- Limit on the amount of CBDC (per person)?

- Due to the "scarcity" of CBDC, its exchange rate with cash might fluctuate

Monopolization of payment data by the central bank?

Jasper of the Bank of Canada, and Payment Canada and Project Ubin of the Monetary Authority of Singapore (Chapman et al., 2017; Monetary Authority of Singapore, 2020).

\section{Recent Developments}

Recent developments, such as the entry of Big Tech firms into payment services and the Libra project, have accelerated studies and experiments on general-purpose CBDCs. As a forerunner, Sveriges Riksbank started studies on its CBDC entitled eKrona in 2016 (Skingsley, 2016). The central bank of Uruguay experimentally issued the e-Peso from November 2017 to April 2018 (Licandro, 2018). In January 2016, the People's Bank of China also disclosed its plan to issue its $\mathrm{CBDC}^{4}$ and in April 2020, started experimentally issuing its CBDC entitled e-CNY in four cities in China (Harada, 2020). In October 2020, the ECB and the Bank of Japan announced their intention to accelerate their research on general-purpose CBDCs (European Central Bank, 2020a; Bank of Japan, 2020). The central bank of The Bahamas officially launched its general-purpose CBDC, Sand Dollar, on October 20, 2020 (Project Sand Dollar, 2020).

\section{Issues in Central Bank Digital Currencies}

Nonetheless, as shown in Table 3, there remain many issues to be overcome before general purpose CBDCs can be launched (Yanagawa \& Yamaoka, 2019). These

\footnotetext{
${ }^{4}$ The official document of the People's Bank of China is available only in Chinese. For a reference in English, see, for example, Reuters (2016).
} 
issues are more challenging to developed economies with well-established banking systems.

\section{Possible Impacts on Bank Deposits}

First, general-purpose CBDCs could cause a shift of funds from bank deposits to CBDCs, since CBDCs are credit-risk-free. Accordingly, bank deposits, which function as the source of bank loans and investments, would decrease and the volume of financial intermediation through banks would decline. On the other hand, the size of the balance sheet of central banks would increase. Since central banks are not in a good position to make loans directly to firms and individuals, the flow of funds from deposits to CBDCs could distort the resource allocation formerly guided by private-sector initiatives, and thereby lead to inefficient resource allocation in the economy.

If banks could offer sufficiently high interest rates on their deposits, they could prevent fund outflows from their deposits to CBDCs. Nonetheless, in countries with extremely low interest rates, it would be difficult to make deposits attractive compared to CBDCs whose interest rate is zero.

\section{Accelerating Digital Bank Runs}

If general-purpose CBDCs are issued, they could be used by anyone, even at midnight and weekends through PCs and smartphones. Thus, if financial markets come under stress due to rumors or other incidents, depositors would immediately move their funds from deposits to CBDCs. Such digital bank runs could be much faster than traditional bank runs, since depositors do not have to be physically present at the bank or ATM to withdraw cash. Accordingly, in a stressful situation, digital bank runs could accelerate the spillover of liquidity problems across borders.

A digital bank run could occur even in the absence of CBDCs since depositors could transfer their deposits to other banks through the Internet. Thus, CBDCs should not be regarded as the single cause of digital bank runs. The question is to what extent CBDCs could amplify the flight to safety. In addition, if the central bank could provide the banking sector with liquidity obtained through the shift of deposits to CBDCs, it could at least compensate for the shortage of liquidity at the macro level. Nonetheless, in the real world, it might not be easy for central banks or financial markets to cover up the source of a liquidity crisis within a very limited timeframe.

\section{Possible Ceilings on the Amount of CBDCs}

In view of the issues above, some argue that there should be a ceiling on the amount of CBDCs held by each entity, or on the value of transactions through CBDCs. They argue that, due to the quantitative ceiling, CBDCs could work as substitutes for banknotes but would not replace deposits.

Nonetheless, in many countries, there is no legal limit on the use of banknotes as legal tender. Having a quantitative ceiling on CBDCs but not on banknotes could create a scarcity in CBDCs so that an exchange rate of 1 by 1 could not be maintained. Since the efficiency of the modern monetary system is based on the assumption that 
cash, central bank deposits, and commercial bank deposits are equitably exchangeable with one another, the possible scarcity premium on CBDCs might reduce the efficiency of the payment infrastructure.

Moreover, risk-free payment instruments are strongly needed in large-value transactions. Indeed, in the present system settling large-value transactions through riskfree central bank money is encouraged, while small value settlements are dealt with mainly by private entities. In Japan, interbank settlements of 100 million JPY or larger are settled through the Bank of Japan Financial Network System (BOJ-NET), which is the central bank real-time gross settlement system, while interbank settlements in amounts lower than 100 million are netted through the Zengin System, which is the private sector based system operated by the Japanese Bankers Association. The Bank of Japan explains that " $(t)$ he changeover to the RTGS [Real-Time Gross Settlement] system was aimed at reducing the systemic risk inherent in designated-time net settlement" (Bank of Japan, 2001). In this regard, the economic rationale of having a quantitative ceiling on CBDCs is unclear.

\section{Possible Impacts on Innovation}

In our present payment and settlement systems, we use major innovative products such as checks, credit cards, debit cards, ATMs and wire transfers that were created through private initiatives. In this regard, if the central bank dominates payment and settlement infrastructures by issuing CBDCs, it could hinder innovation by private entities.

\section{Impacts on Data Utilization}

If the central bank, by issuing CBDCs, collects and accumulates the data related to daily transactions, it would become difficult for private entities to utilize the data. It might prove challenging for central banks to fully utilize the data accumulated through CBDCs, and the data attached to transactions through CBDCs in the economy.

In addition, the accumulation of gigantic amounts of data by the central bank might raise sensitive issues regarding its independence, especially if these data could potentially be exploited for other purposes such as taxation and crime prevention. Whether or not the central bank could allow tax agencies or the police to make full use of such transaction data is a delicate issue. In many countries, central banks are independent from the administrative power of the government, based on the assumption that the central bank keeps a distance from administrative actions.

\section{CBDCs and Monetary Policy}

There are also many CBDC issues regarding monetary policy. These issues are critical especially for countries with independent currencies and monetary policy.

\section{Positive Interest Rate on CBDCs}

First, some scholars argue that CBDCs should be interest-bearing (Bordo \& Levin, 2017). One of the reasons for this is that interest rates on CBDCs could constitute a 
hard floor for a wide range of interest rates so that central banks could use it as an operational tool.

However, if the CBDC interest rate is positive, the shift of funds from deposits to CBDCs could be accelerated. Moreover, if CBDCs are designed to replace cash and not deposits, there is no strong reason to offer positive interest rates on CBDCs.

\section{Negative Interest Rate on CBDCs}

Second, there is also an argument that CBDCs could contribute to overcoming the zero-lower bound and facilitate a negative interest rate policy, since simply cutting the nominal value of CBDCs would enable deeply negative interest rates (Bordo \& Levin, 2017; Haldane, 2015).

Nonetheless, as long as paper-based banknotes continue to exist, the zero-lower bound will remain. It will be extremely difficult for central banks to completely abolish cash, since cash has its own benefits, such as not relying on the supply of electricity. Indeed, cash proved to be an effective payment tool even in the large-scale blackout caused by the earthquake in Hokkaido, Japan, in 2018. As long as individuals can still use cash for various payments, without having to use a PC, a mobile phone, or a smartphone, cash remains a convenient tool. Under these environments, imposing negative interest rates on CBDCs could trigger the shift of funds from CBDCs to cash. If people prefer cash to CBDCs, then the rationale for issuing CBDCs might be lost.

Moreover, it is not certain whether cutting the nominal value of CBDCs would have positive or negative impacts on expenditures. A negative remuneration of CBDCs would substantially undermine confidence in central banks issuing them (Mersch, 2017).

\section{CBDCs and the Modern "Two-Tiered" Monetary System}

Digital innovation fosters new challengers, such as Big Tech firms and Libra, to the modern monetary system based on nation states. CBDCs could be understood as the authorities' efforts to utilize digital technologies independently to maintain the controllability of money. At the same time, general-purpose CBDCs might have the possibility to challenge the "two-tiered" structure, which is another aspect of the modern monetary system. Indeed, general-purpose CBDCs have the potential to transform the two-tiered structure into a single-tiered one, depending on their design.

Central banks studying or experimenting with general-purpose CBDCs argue that they will maintain the two-tiered structure and that CBDCs, if launched, would be issued indirectly (European Central Bank, 2020b; Bank of Japan, 2020). ${ }^{5}$ In other words, central banks issue general-purpose CBDCs directly to banks and payment service providers, and these private entities convey CBDCs to firms and individuals.

\footnotetext{
5 The European Central Bank (2020b) states that "(a)n intermediated access model is preferable." The Bank of Japan (2020) states that "(e)ven if the Bank were to issue general-purpose CBDC, it would still be appropriate to maintain a two-tiered payment and settlement system of a central bank and the private sector," and that "( $\mathrm{t}$ )his means that CBDC would be issued indirectly through intermediaries.".
} 
Under this indirect scheme, banks would offer both deposits as their own liabilities and CBDCs as central bank liabilities. However, there have been many institutional frameworks, such as banking regulations, supervision, and deposit insurance, aimed at securing the safety of deposits and at guaranteeing equitable exchanges of deposits and cash. Thus, CBDC issues will require reviewing the rationale of banking regulation, supervision, and deposit insurance as well as the modern monetary system itself. These issues are also deeply connected to the classical debates on narrow banking (Kobayakawa \& Nakamura, 2000). ${ }^{6}$ For example, in 1987 Professor James Tobin proposed that the government should offer payment tools "with the convenience of deposits and the safety of currency" to the public. He also proposed two ways in which such tools could be offered: The first way was that the central bank itself could offer such tools, and the second way was that private banks could offer such tools that would be invested entirely in central bank money or short-term treasury securities, so that they would not have to be insured (Tobin, 1987).

\section{The Potential of Digital Currencies Issued by Private Entities}

\subsection{Issues to Be Resolved in Japan's Payment Infrastructure}

It is vital for advanced economies with well-developed banking systems to make full use of the benefits of the modern monetary system while applying new digital technologies. In addition, the experience of COVID-19 has reminded us of the importance of digitizing the economy in order to maintain economic activity while social distancing. In this respect, the digital transformation (DX) of the economy and digitalized payments are more needed than ever. Regarding CBDCs, there are many relevant issues related to economic efficiency, financial stability, monetary policy, and data utilization. As any payment instrument, including cash, has strong network externalities, it is difficult to determine how long it will take for digital payment tools to outstrip cash, as this may depend largely on country-specific conditions. For example, in countries where cash is widely used, it would take time for digital payment tools to replace cash due to its strong network externalities. Moreover, especially in countries with low interest rates, the demand for cash would remain strong, mainly for storing value. Nonetheless, the digitization of payments will generally continue, and the use of digital payment instruments is expected to be further popularized over the medium term.

First, as digital innovation fosters the development of various digital-based activities such as e-commerce, firms and individuals are becoming more aware of the costs of handling cash. Although consumers do not directly bear the costs of handling

\footnotetext{
${ }^{6}$ Kobayakawa and Nakamura (2000) state that "narrow banks are broadly referred to as ones specializing in deposit-taking/payment activities that do not provide lending services.".
} 
cash, handling, storing, and conveying cash are often costly, especially for firms and financial institutions.

In this regard, digital payment instruments are needed since they are expected to reduce the costs, enhance the efficiency and promote the development of new businesses. Utilizing digital technologies in payments is critical in fostering new economic activities, such as e-commerce, sharing economies, and "as a Service" applications ["anything as a service" (XaaS)], through the use of data associated with payments (Financial Stability Board, 2019).

Also, being considered the "oil of the twenty-first century," data are intangible assets whose importance is growing, and digital payment instruments are now attracting great attention as tools for collecting data. In this regard, the ongoing "data revolution" is the driving force of promoting digital money. Cash can only convey data concerning the value by which its owner can purchase goods or services with the equivalent value. On the other hand, digital payment instruments can handle a variety of data, like who buys what, when, and where. Many firms are now providing digitalized payment services in order to collect customer data by giving incentives and discounts to customers.

In order to overcome the issues associated with CBDCs while obtaining these benefits of data revolution, one possible option is to issue private-based and twolayered digital currencies, which are denominated by sovereign currency units and incorporate advanced technologies such as blockchain and smart contracts.

\subsection{The Concept of "Private-Led" and "Two-Layered" Digital Currency}

Japan's payment infrastructure faces many challenges. Japan remains one of the most cash-oriented countries, where cash is heavily used for transactions and as a form of value storage (Ōtani and Suzuki, 2008). ${ }^{7}$ Accordingly, Japan bears substantial costs associated with cash. Moreover, reliance on cash makes it difficult to utilize data attached to payments and settlements. Although there are many digital payment platforms available, they are rarely inter-operable and users need to choose from many payment options, including cash, in each transaction.

In light of these issues, in June 2020 the three mega-banks, leading non-financial companies, and experts in Japan established the Study Group on Digital Currency Settlement Infrastructure, where the author of this chapter acted as the chairperson. Relevant ministries, the Financial Services Agency and the Bank of Japan also participated as observers. The Study Group carried out intensive studies on relevant issues, with a view of innovating payment infrastructures through private-sector initiatives and promoting the DX of Japan's economy. The Study Group also hopes for Japan

\footnotetext{
${ }^{7}$ In Japan, cash is not hoarded "under mattresses," but put away in dressers (tansu). Japanese households hoarding cash, therefore, are said to have "dresser deposits" (tansu yokin) (Ōtani and Suzuki, 2008) in place of bank deposits (ginkō yokin).
} 


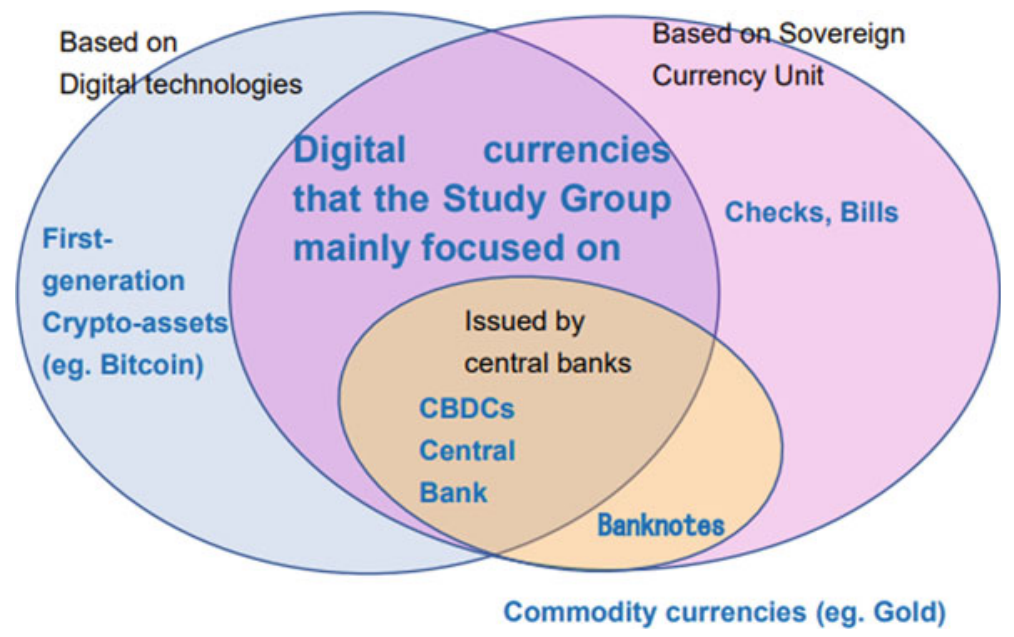

Fig. 1 Research scope of the "Study Group on Digital Currency Settlement Infrastructure". Source "Innovation of Payment Infrastructure and Potential of Digital Currencies in Japan" (Study Group on Digital Currency Settlement Infrastructure, 2020)

to become a leading country in terms of innovating financial infrastructures. The Group reviewed possible designs and the feasibility of digital currencies so they could contribute to innovating payment infrastructures.

Among a variety of options, the Group agreed that digital currency issued by private entities and denominated by JPY should be one of the most promising options, and agreed to further examine its potential and applicability to various use cases (Fig. 1).

In order for digital currencies to contribute to the economy, their infrastructure should be stable, highly secure, resilient, and reliable. It should also be available for a wide range of users and for long hours, and be inter-operable with each other. Moreover, it should continuously evolve by flexibly adopting new technologies and innovate themselves. These attributes will be necessary for digital currency to promote innovation and economic development by facilitating fair competition while supporting cooperation among the relevant entities.

In view of these requirements that digital currencies are expected to satisfy, the Study Group agreed that digital currency with a "two-layered" structure is a promising option, and that private entities such as banks can issue it.

This two-layered digital currency consists of its lower layer (the "common" field) and its upper layer (the programmable field for value added) (Fig. 2). The upper layer will be equipped with customized programs to meet various business needs, so that the digital currency can enhance the efficiency of payments and facilitate high-speed and sophisticated transactions. Business needs may vary, including coordination and synchronization of logistics, commercial distribution and finance, supply chain management, delivery versus payment (DvP) of securities and funds, and streamlining of back-office operations. The lower layer contains value-related information 


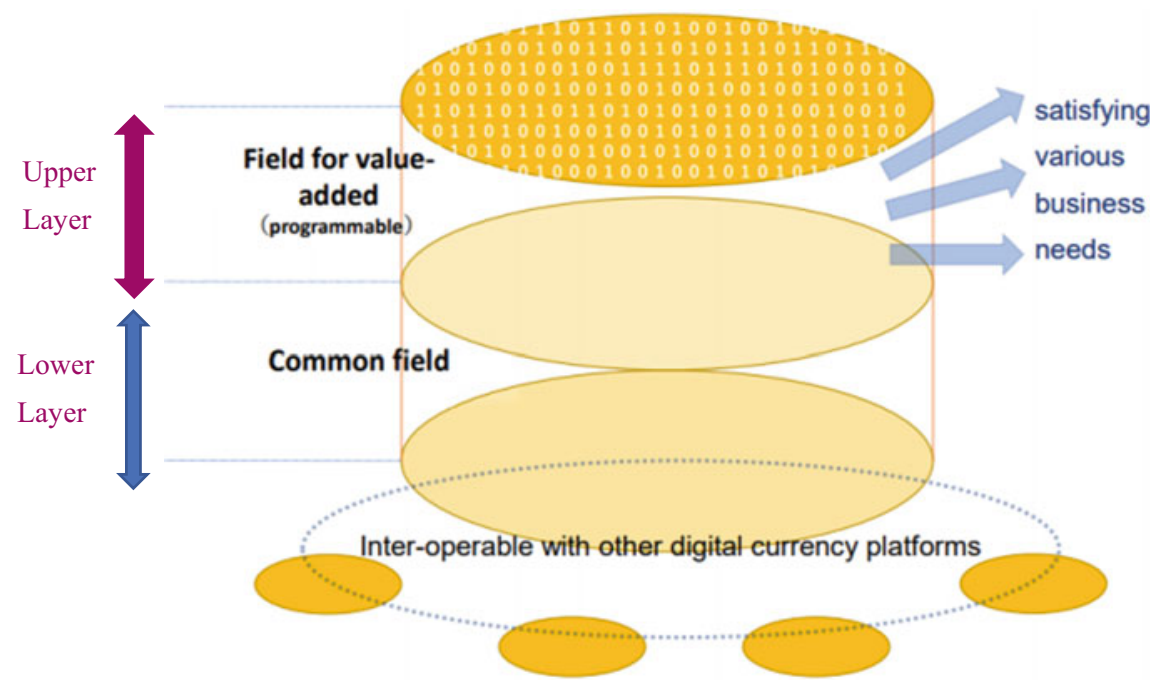

Fig. 2 Two-Layered Digital Currency. Source "Innovation of Payment Infrastructure and Potential of Digital Currencies in Japan" (Study Group on Digital Currency Settlement Infrastructure, 2020)

such as how much JPY a digital currency represents. Since all the digital currencies issued in this scheme share the same structure in the lower layer, they will become inter-changeable with each other, regardless of what kind of customizfed programs are written in the upper layer.

The two-layered digital currency denominated by JPY and issued by private entities such as commercial banks may have several benefits:

- It maintains financial intermediation led by private-sector initiatives.

- It makes use of existing frameworks for maintaining the credibility of money, including banking regulation and supervision. If non-banks become its issuers, they can secure its credibility by backing it up completely with safe assets, as Libra (currently Diem) is trying to do. If the central bank operates its RTGS system on a 24/7 basis and allows the issuers of digital currencies to participate in it, the digital currencies issued by private entities will be almost as safe as CBDCs.

- It applies new DLT technologies such as blockchain and smart contracts in its upper layer in order to enhance the efficiency of various economic activities.

- It promotes inter-operability of various payment platforms by utilizing the lower layer, which is common in all of the digital currencies issued under this scheme (Fig. 3).

- It makes use of private-sector initiatives to innovate payment and settlement infrastructures. In the two-tiered monetary system, private entities compete with each other to provide innovative payment services such as internet banking and mobile payments, while using common currency units such as the dollar and the yen. By maintaining the benefit of the two-tier monetary system, the two-layered digital 


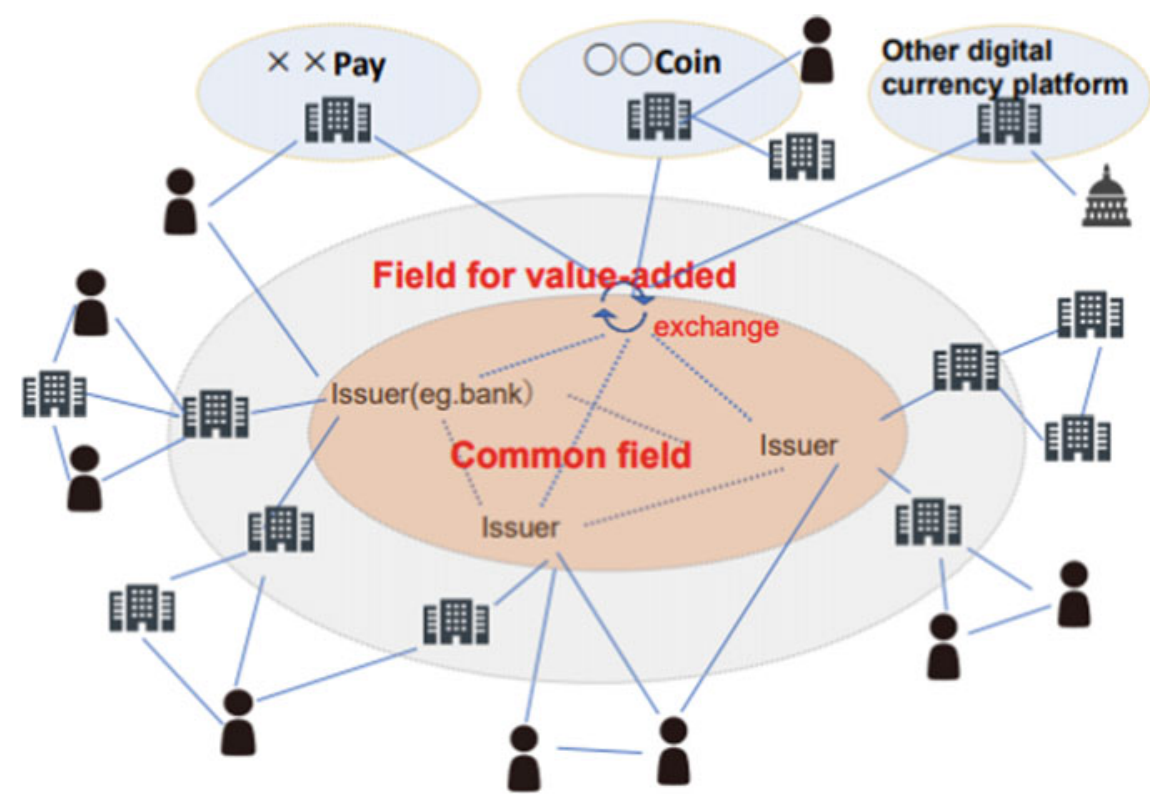

Fig. 3 Two-layered digital currency and its inter-operability. Source "Innovation of Payment Infrastructure and Potential of Digital Currencies in Japan" (Study Group on Digital Currency Settlement Infrastructure, 2020)

currency can strike a balance between payment stability and private sector-led innovation.

- It facilitates the use of the data attached to payments and settlements by private entities.

There are plans for this two-layered digital currency to co-exist with current digital payment instruments (such as electronic money and credit and debit cards), centralized payment infrastructures (such as the Zengin system), or CBDCs. The two-layered digital currency will be able to enhance the inter-operability of these payment platforms by bridging them. The Study Group argued that payment innovation adopting new technologies and led by private-sector initiatives enhances the efficiency and convenience of wide-ranging transactions, and contributes to the DX of the economy.

\subsection{The Digital Currency Forum}

In November 2020, the Study Group developed into the Digital Currency Forum (Fig. 4), where many new member firms joined. The Forum now consists of leading 


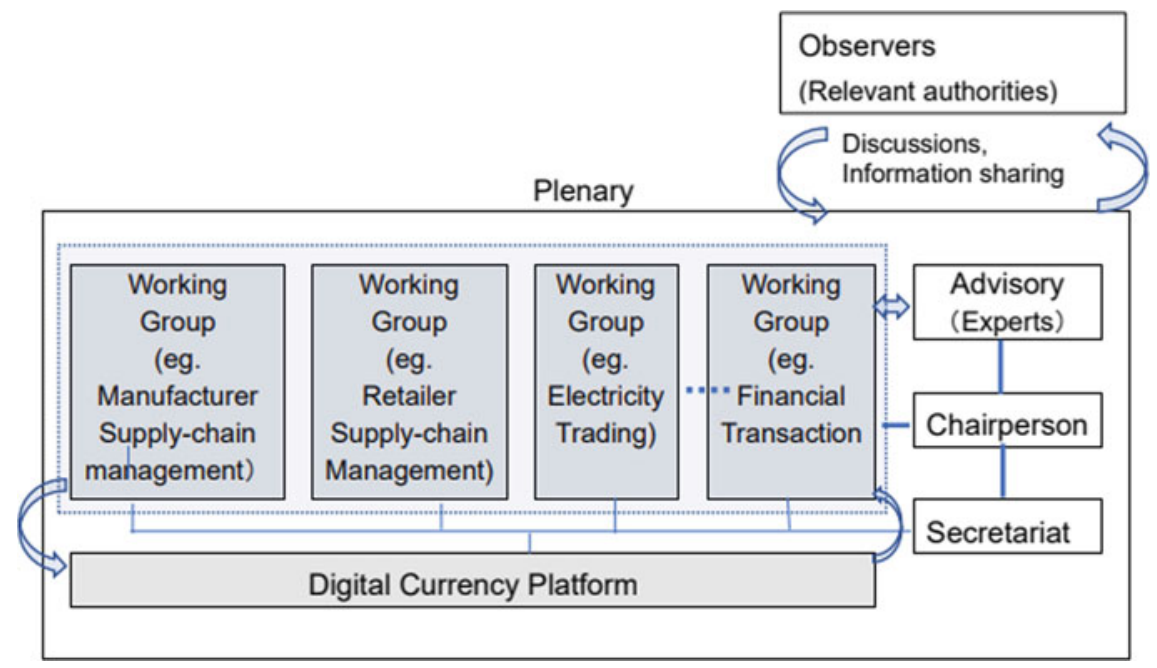

Fig. 4 Structure of the Digital Currency Forum. Source "Innovation of Payment Infrastructure and Potential of Digital Currencies in Japan" (Study Group on Digital Currency Settlement Infrastructure, 2020)

banks, non-financial companies and experts, including both the original members of the Study Group and new participants (Table 4).

The Study Group selected various use cases in which two-layered digital currencies can be effective in enhancing efficiency and overcoming business obstacles (Table 5 and Fig. 5). What is needed as the next step is to develop the ideas and concepts into actions and initiatives. In view of these tasks, the Digital Currency Forum, which the author of this chapter chairs, will conduct various actions and initiatives, such as the Proof of Concept $(\mathrm{PoC})$ applying digital currency to possible use cases and a review of related issues such as desirable reforms of business practices.

The Forum also facilitates the sharing of information, lively discussion among stakeholders, and the cooperation of relevant entities across Japan. Through these activities, the Forum promotes the innovation of payment infrastructures and the establishment of an efficient eco-system. The Forum tries to leverage new technologies and private-sector initiatives, and to contribute to enhancing the efficiency and convenience of Japan's financial infrastructure, and the DX of Japan's economy.

Before issuing the two-layered digital currency, it will be necessary to clarify the legal and institutional framework for it, in order to overcome technological hurdles and to analyze its economic impact more deeply. Accordingly, the Forum established an Advisory Board consisting of experts on laws, accounting, technologies, and economics (Fig. 4).

In order to make full use of the innovation of payment infrastructures for the DX of Japan's economy, it will be beneficial to go beyond the application of digital technology to payments and to review comprehensively the way in which economic activities and business practices are carried out. In order to promote the DX of the 
Table 4 Members of the Digital Currency Forum (as of November 19, 2020)

\begin{tabular}{|c|c|c|}
\hline \multicolumn{3}{|c|}{ Original Members of the Study Group } \\
\hline $\begin{array}{l}\text { (Chairperson) Hiromi } \\
\text { Yamaoka } \\
\text { (Member of the Board, Future } \\
\text { Corp. Former DG of Payment } \\
\text { and Settlement Systems Dept., } \\
\text { BoJ) } \\
\text { MUFG Bank, Ltd. } \\
\text { Sumitomo Mitsui Banking } \\
\text { Corporation }\end{array}$ & $\begin{array}{l}\text { Mizuho Bank, Ltd. } \\
\text { Seven Bank, Ltd. } \\
\text { (Seven \& I Holdings Co., Ltd.) } \\
\text { NTT Group } \\
\text { East Japan Railway Company }\end{array}$ & $\begin{array}{l}\text { KDDI Corporation } \\
\text { Internet Initiative Japan Inc. } \\
\text { Mori Hamada \& Matsumoto } \\
\text { Accenture Japan Ltd. } \\
\text { SIGMAXYZ Inc. }\end{array}$ \\
\hline \multicolumn{3}{|c|}{ New Members Joining with the Establishment of the Forum } \\
\hline $\begin{array}{l}\text { Aeon Co., Ltd. } \\
\text { ANA Group } \\
\text { The Kansai Electric Power } \\
\text { Company Inc. } \\
\text { KYOCERA Corporation } \\
\text { Kesennuma City } \\
\text { JCB Co., Ltd. } \\
\text { Sumitomo Life Insurance } \\
\text { Company } \\
\text { SECOM Co., LTD. } \\
\text { SOHGO SECURITY } \\
\text { SERVICES Co., LTD } \\
\text { (ALSOK) }\end{array}$ & $\begin{array}{l}\text { Sony Bank Incorporated } \\
\text { Sompo Holdings, Inc. } \\
\text { DAIDO LIFE INSURANCE } \\
\text { COMPANY } \\
\text { Daiwa Securities Group Inc. } \\
\text { Chubu Electric Power Co., Inc. } \\
\text { TIS Inc. } \\
\text { DENTSU Inc. } \\
\text { Tokyo Marine \& Nichido Fire } \\
\text { Insurance Co. } \\
\text { Tokyo Financial Exchange Inc. }\end{array}$ & $\begin{array}{l}\text { Toppan Printing Co., Ltd. } \\
\text { Nomura Holdings, Inc. } \\
\text { Hitachi, Ltd. } \\
\text { FamilyMart Co., Ltd. } \\
\text { Mitsui Sumitomo Insurance } \\
\text { Co., Ltd. } \\
\text { Sumitomo Mitsui Trust Bank, } \\
\text { Limited } \\
\text { Mitsubishi UFJ Research and } \\
\text { Consulting Co., Ltd. } \\
\text { JAPAN POST BANK Co., } \\
\text { Ltd. } \\
\text { Lawson, Inc. }\end{array}$ \\
\hline
\end{tabular}

Advisors

Masakazu Masujima, Partner, Mori Hamada \& Matsumoto

Tetsuya Inoue, Chief Researcher, Nomura Research Institute, Ltd.

Shuji Kobayakawa, Professor, School of Political Science and Economics, Meiji University

Kenji Saito, Professor, Graduate School of Business and Finance, Waseda University

Chikako Suzuki, Certified public accountant

Observers

Financial Services Agency

Ministry of Internal Affairs and Communication

Ministry of Finance

Ministry of Economy, Trade and Industry

Bank of Japan

Source "Innovation of Payment Infrastructure and Potential of Digital Currencies in Japan" (Study Group on Digital Currency Settlement Infrastructure, 2020).

economy it will be vital to build an ecosystem that can make full use of integrated digital payment infrastructures. 
Table 5 Possible use cases of digital currency

Fig. 5 Possible Use Cases of Digital Currency-Supply Chain. Source "Innovation of Payment Infrastructure and Potential of Digital

Currencies in Japan" (Study Group on Digital Currency Settlement Infrastructure, 2020)

\begin{tabular}{l|l}
\hline $\begin{array}{l}\text { a. Supply chain of } \\
\text { manufacturers (Fig. 5) }\end{array}$ & $\begin{array}{l}\text { k. Royalty rewards and local } \\
\text { economies }\end{array}$ \\
\hline b. Supply chain of retailers & 1. Financing, fundraising \\
\hline c. Logistics & m. Credit card operations \\
\hline $\begin{array}{l}\text { d. Transactions of financial } \\
\text { assets }\end{array}$ & n. Insurance \\
\hline $\begin{array}{l}\text { e. Trade finance } \\
\text { f. Electricity trading }\end{array}$ & $\begin{array}{l}\text { o. Transactions of } \\
\text { non-fungible tokens (NFTs) }\end{array}$ \\
\hline $\begin{array}{l}\text { g. Linkages of e-money and } \\
\text { digital currency }\end{array}$ & quability as a Service \\
\hline $\begin{array}{l}\text { h. Inter-bank settlements } \\
\text { i. Regional currency, } \\
\text { community money }\end{array}$ & $\begin{array}{l}\text { r. Off-line payments between } \\
\text { smartphones }\end{array}$ \\
\hline j. Administrative operations & $\begin{array}{l}\text { s. Cash management of } \\
\text { business groups }\end{array}$ \\
\hline
\end{tabular}

Source "Innovation of Payment Infrastructure and Potential of Digital Currencies in Japan" (Study Group on Digital Currency Settlement Infrastructure, 2020)

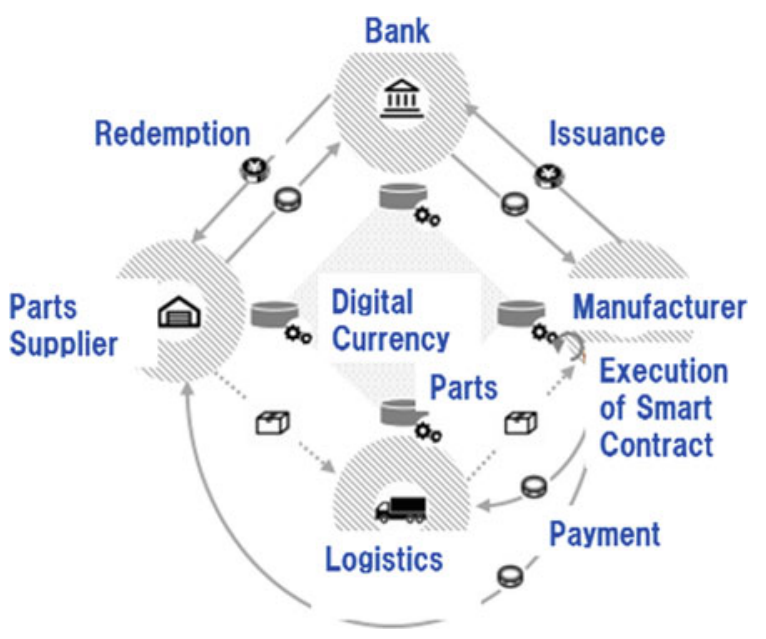




\section{Digital Currency and the Future of the Monetary System}

\subsection{Challenges to the Modern Monetary System Triggered by Digital Innovation}

To conclude this chapter, the last section tries to provide the prospects of the monetary system in the future, and to explain how the initiatives of the Digital Currency Forum could contribute to enhancing the utility and the credibility of the monetary infrastructure in Japan.

The modern monetary system, which consists of the central bank as a single issuer of sovereign currency and a two-tiered structure, was established at the final stage of modern nation states in the nineteenth century (Yamaoka, 2019). The introduction of digital currencies provides the opportunity to reconsider the rationale of this system.

Recent digital innovation has brought about various new challenges to the system, and these challenges include crypto-assets, the entry of Big Tech into payment services, and ambitious projects like Libra led by Facebook. CBDCs could be regarded as the authorities' efforts to maintain the controllability of the monetary system by utilizing digital technologies independently. Nonetheless, CBDCs in turn might influence two-tiered structures of the modern monetary system.

Digital currency issued by private entities could contribute to enhancing the efficiency of economic transactions by making use of digital technologies while securing inter-operability of various payment platforms. The Digital Currency Forum is trying to utilize the scheme of two-layered digital currency, which could incorporate programmable parts in the upper layer while maintaining the two-tiered structure of the monetary system.

Moreover, this two-layered digital currency issued by private entities will not impair the effectiveness of monetary policy. If crypto-assets not denominated in sovereign currency units become widely used for transactions, the effectiveness of monetary policy could be substantially impaired. Theoretically, this situation is similar to dollarization, where foreign currencies are widely used instead of domestic currencies. In this regard the two-layered digital currency proposed by the Forum will enhance the utility of JPY, and thereby contribute to the effectiveness of monetary policy.

\subsection{The Monetary System and Nation States}

Digital currency gives us the opportunity to review the modern monetary system. The trust and credibility of the modern monetary system has been secured by various institutional frameworks based on nation states, laws, taxation, banking regulation and supervision and deposit insurance. Central banks are also inventions of the postseventeenth-century era of nation states. Indeed, the framework of nation states has worked as a trust machine backing up the modern monetary system (Yamaoka, 2019). 
Within a relatively short period, the modern monetary system has become a globally shared design, in which the central bank of each state is the sole issuing authority of the sovereign currency, and commercial banks provide deposits as convenient private money.

In this regard, bitcoin, which belongs to the first-generation crypto-assets, tries to create trust and credibility from scratch without relying on nation states, and may entail substantial costs in terms of electricity consumption in relation to mining (Criddle, 2021). ${ }^{8}$ The fact that the first-generation crypto-assets have not been used widely as payment instruments implies that a framework for creating trust and credibility that works better than nation states has not yet been found.

In this regard, Libra has interesting characteristics as a stable coin: All indications are that it will be backed up fully by safe assets denominated by credible sovereign currencies (Diem Association, 2020). This scheme means that Libra tries to make use of the trust of key currencies in order to stabilize its value. In this regard, Libra could be regarded as a combination of crypto-assets and sovereign currencies and could be understood as a scheme to borrow the framework of nation states to create trust and credibility.

In view of these developments, it is unlikely that the monetary system in the near future will operate outside of nation states. As long as nation states maintain trust and credibility, it will be difficult for crypto-assets to replace sovereign currencies.

At the same time, the DLT behind crypto-assets such as blockchain may have great potential. If these technologies are successfully combined with the trust and credibility of existing currencies, they could contribute to enhancing the efficiency of payments, settlements, and the economy. The two-layered digital currency, which the Digital Currency Forum is trying to realize, will be one of the options to achieve these goals.

\subsection{The Monetary System and the Two-Tiered Structure}

The two-tiered structure in the monetary system will be maintained at least for the foreseeable future. The case in which CBDCs transform the current two-tiered structure into a single-tiered structure is similar to the idea of narrow banking. Nonetheless, many issues need to be further examined in this respect. If CBDCs substantially replace not only banknotes but also bank deposits, it would squeeze credit intermediation through banks and inflate the central bank's balance sheet instead. Central banks are neither destined to make loans directly to firms or individuals, nor suitable for evaluating the risks and returns of various projects. Accordingly, a CBDC replacement of deposits could distort the allocation of resources. Although banks could pay interests on their deposits to maintain their attractiveness over CBDCs, it may not be easy for them to offer sufficiently high interest rates on demand deposits, especially in low interest rate environments. Moreover, it is unlikely that the central bank would

${ }^{8}$ According to Criddle (2021), the mining for bitcoin "consumes more electricity than Argentina". 
continuously innovate the payment infrastructure, utilize smart contracts to facilitate each business need, or manage anti-money laundering (AML) in combating the financing of terrorism (CFT). Nonetheless, the participants in this two-tiered structure will become more diversified, and not only banks but also non-bank payment service providers and Big Tech firms are expected to play important roles in the payment infrastructure.

In this regard, if the central bank allows a larger range of direct participants to participate in their settlement systems and extend their operating hours, they might reap some of the potential benefits of CBDCs. Indeed, several systems such as the TARGET Instant Payment Settlement (TIPS) launched by the ECB, and the New Payments Platform (NPP) by the Reserve Bank of Australia, started to operate on a 24/7 basis in order to support private-sector-based digital payments in 2018 (Bullock, 2018; Mersch, 2018). Since 2018, the Bank of England has also allowed non-bank payment service providers to directly join its RTGS system, and since 2019, Swiss National Bank started allowing Fintech companies access to Swiss Interbank Clearing (Bank of England, 2018, and Swiss National Bank, 2019). These options could continue to be sought, in parallel with studies on CBDCs.

\subsection{Competition Among Currencies}

Digital innovation could intensify the competition among currencies by reducing the cost of using multiple types of payment instruments. Currencies without sufficient credibility and utility might lose their presence more easily than before.

As most countries came to have their own central banks in the last century, the number of central banks gradually increased and became almost equal to the number of nations. Following that, however, there has been a growing trend towards currency union, and by the end of the last century the ECB was established. The ECB, as well as several other initiatives in Africa and the Caribbean states, could be regarded as part of a wider effort to reduce the cost of cross-border transactions through the sharing of a central bank and of a common currency unit. Although central banks are still needed, having one's own central bank may no longer be a necessary condition to remain a nation state. Nations are increasingly capable of sharing a central bank, provided they join forces to create a robust and effective framework that guarantees its trustworthiness and credibility through the harmonization of diverse economic policies and infrastructures. Accordingly, the future monetary system would consist of several key currencies and satellite currencies that try to maintain their credibility and utility by linking them to one of those key currencies or basket of currencies. Under these environments, each jurisdiction is required to make more efforts towards enhancing the efficiency and utility of their payment and settlement infrastructures, if they want to maintain their own currency. 


\subsection{Public and Private Initiatives to Shape the Future of the Monetary System}

If we think about the future of the monetary system, we cannot avoid thinking about the relationship between currencies and data. The monetary system in the future should facilitate the utilization of data by society in a safe and reliable manner.

From the origin of its history, money has translated the value of various goods and services into prices with common units, and enabled price mechanisms to function effectively. Thanks to money, we can measure general price levels and inflation. As such, money works as a critical tool for processing information and data in the economy.

In the current two-tiered monetary system, central banks obtain the information and data they need for maintaining the overall stability of payment and settlement systems. On the other hand, insofar as banknotes are anonymous instruments, central banks do not have access to the information and data attached to daily transactions carried out by ordinary people. These data have long been exploited mainly by private hands.

Traditionally, financial institutions used to gather financial data while nonfinancial companies mainly collected non-financial data. But with the kind of digitalbased transactions entailed by e-commerce, financial and non-financial data are increasingly interlinked with each other. As digitized payment instruments develop, they are playing a greater role in collecting and processing a variety of data attached to payments and settlements. The accelerating accumulation and utilization of customer data with financial and non-financial data are bound to become more closely interlinked with each other. That is the major reason why many Big Tech firms are entering into digital payment services.

In such an environment, the new monetary system is expected to facilitate the utilization of not only financial but also non-financial data in a safe and reliable manner. As digital innovation enables payment instruments to function as tools for conveying and processing a variety of data, ensuring data security, privacy and anonymity are becoming crucial issues in the financial services industry. It may not be feasible for the central bank to bear all the responsibility in this respect, and effective cooperation between private entities, regulatory agencies, and the central bank will be essential.

In such an environment, whether the monetary system can facilitate the utilization of data in a safe and effective manner will substantially influence the efficiency of the economy. In this regard, one of the critical issues regarding CBDCs is also its impact on the use of data. In thinking about the future monetary system, it is important to design the optimal style and distribution of roles regarding the use of the data attached to economic transactions. 


\section{Outlook}

In 2008, when we were in the midst of a global financial crisis, crypto-assets, blockchains, and DLTs were nowhere to be seen. The iPhone, Kindle, Uber, and Airbnb were still in their infancy. Nobody had yet pressed Facebook or Instagram's Like button. Since then, the number of smartphones has increased dramatically, and Big Tech firms have grown very rapidly and have become top global firms. These instruments and firms are now playing important roles also in digital payments. As such, the ongoing digital innovations are influencing also the style of currencies in various ways.

Given the complexity of the challenges and the different fields of expertise involved, the future of the monetary system will necessarily be shaped by both public and private initiatives. As for Japan, the Digital Currency Forum will continue to mobilize private resources while closely cooperating with public entities to maintain the credibility of Japan's currency system and to enhance the utility of payments and settlement infrastructures.

\section{References}

Bank of England. (2018, April 18). First non-bank payment service provider (PSP) directly accesses UK payment system. https://www.bankofengland.co.uk/news/2018/april/non-bank-psp-accessto-the-payments-system-announcement

Bank of Japan. (2001, November). Real-time gross settlement (RTGS) in Japan: An evaluation of the first six months. Quarterly Bulletin. https://www.boj.or.jp/en/research/brp/ron_2001/data/ron 0111a.pdf

Bank of Japan. (2016, December 7). ECB and the Bank of Japan launch a joint research project on distributed ledger technology. https://www.boj.or.jp/en/announcements/release_2016/rel161 207a.htm/

Bank of Japan. (2017, February). Executive summary of the conference on FinTech and the future of money. https://www.boj.or.jp/en/announcements/release_2017/data/rel170208a1.pdf

Bank of Japan. (2020, October 9). The Bank of Japan's approach to central bank digital currency. https://www.boj.or.jp/en/announcements/release_2020/data/rel201009e1.pdf

Bordo, M., \& Levin, A. (2017). Central bank digital currency and the future of monetary policy (NBER Working Paper No. 23711). National Bureau of Economic Research. https://www.nber. org/system/files/working_papers/w23711/w23711.pdf

Bullock, M. (2018, March 13). Fast payments in Australia. Reserve Bank of Australia. https://www. rba.gov.au/speeches/2018/sp-ag-2018-03-13.html

Chapman, J., Garratt, R., Hendry, S., McCormack, A., \& McMahon, W. (2017). Project Jasper: Are distributed wholesale payment systems feasible yet? Bank of Canada. Financial System Review, June 2017. https://www.bankofcanada.ca/wp-content/uploads/2017/05/fsr-june-2017-chapman. pdf

Committee on Payment and Settlement Systems. (2003, August). The role of central bank money in payment systems. Bank for International Settlements. https://www.bis.org/cpmi/publ/d55.pdf

Criddle, C. (2021, February 18). Bitcoin consumes 'more electricity than Argentina'. BBC News. https://www.bbc.com/news/technology-56012952

Diem Association. (2020, December 1). The official white paper. Retrieved September 30, 2021.https://www.diem.com/en-us/white-paper/ 
European Central Bank. (2020a, October 2). ECB intensifies its work on a digital euro. https://www. ecb.europa.eu/press/pr/date/2020/html/ecb.pr201002 f90bfc94a8.en.html

European Central Bank. (2020b, October). Report on a digital euro. https://www.ecb.europa.eu/ pub/pdf/other/Report_on_a_digital_euro 4d7268b458.en.pdf

Financial Stability Board. (2019, February 14). FinTech and market structure in financial services: Market developments and potential financial stability implications. https://www.fsb.org/wp-con tent/uploads/P140219.pdf

Haldane, A. (2015, September 18). How low can you go? Bank of England. https://www.bankof england.co.uk/speech/2015/how-low-can-you-can-go

Haldane, A. (2018, April 19). Will big data keep its promise? Bank of England. https://www. bankofengland.co.uk/-/media/boe/files/speech/2018/will-big-data-keep-its-promise-speech-byandy-haldane.pdf

Harada, I. (2020, May 7). China aims to launch digital yuan by 2022 Winter Olympics. Nikkei Asia. https://asia.nikkei.com/Spotlight/Cryptocurrencies/China-aims-to-launch-digital-yuan-by2022-Winter-Olympics

International Monetary Fund, \& World Bank. (2019, June 27). Fintech: The experience so far (Policy Paper No. 19/024). https://www.imf.org/en/Publications/Policy-Papers/Issues/2019/06/ 27/Fintech-The-Experience-So-Far-47056

Kobayakawa, S., \& Nakamura, H. (2000). A theoretical analysis of narrow banking proposals. Monetary and Economic Studies, 18(1), 105-118. Bank of Japan. https://www.imes.boj.or.jp/res earch/papers/english/me18-1-4.pdf

Licandro, G. (2018, November 16). Uruguayan e-Peso on the context of financial inclusion. Bank for International Settlements. https://www.bis.org/events/eopix_1810/licandro_pres.pdf

Lowe, P. (2021, March 15). Opening remarks to the Melbourne business analytics conference. Reserve Bank of Australia. https://www.rba.gov.au/speeches/2021/sp-gov-2021-03-15.html

Maes, I. (2018). Central banking through the centuries (Working Paper No. 345). National Bank of Belgium. https://www.nbb.be/doc/ts/publications/wp/wp345en.pdf

Monetary Authority of Singapore. (2020). Project Ubin: Central bank digital money using distributed ledger technology. https://www.mas.gov.sg/schemes-and-initiatives/project-ubin

Mersch, Y. (2017, January 16). Digital base money: an assessment from the ECB's perspective. European Central Bank. https://www.ecb.europa.eu/press/key/date/2017/html/sp170116.en.html

Mersch, Y. (2018, November 30). TIPS and the future of innovative retail payment solutions in Europe. European Central Bank. https://www.ecb.europa.eu/press/key/date/2018/html/ecb.sp1 81130.en.html

Ōtani, S. \& Suzuki, T. (2008). Ginkōken • ryūdōsei yokin no takadomari ni tsuite [The high level of banknotes and liquid deposits]. Bank of Japan Review, 2008-J-9, Bank of Japan. https://www. boj.or.jp/research/wps_rev/rev_2008/data/rev08j09.pdf

Project Sand Dollar. (2020, October 20). Nationwide launch. https://www.sanddollar.bs/publicupd ates/nationwide-launch

Reuters. (2016, January 20). China's central bank plans to launch its own digital currencies. https:// www.reuters.com/article/us-china-currency-digital-idUSKCNOUY1JT

SINTEF. (2013, May 22). Big Data, for better or worse: $90 \%$ of world's data generated over last two years. ScienceDaily. www.sciencedaily.com/releases/2013/05/130522085217.htm

Skingsley, C. (2016, November 16). Should the Riksbank issue e-krona? Sveriges Riksbank. https://www.riksbank.se/en-gb/press-and-published/riksbanken-play/2016/skingsley-sho uld-the-riksbank-issue-e-krona/

Study Group on Digital Currency Settlement Infrastructure. (2020, November 19). Nihon no kessai infura no inobēshon to dejitaru tsūka no kanōsei [Innovation of payment infrastructure and potential of digital currencies in Japan]. https://news.decurret.com/hc/ja/article_attachments/360 097791374/.pdf

Swiss National Bank. (2019, January 11). Swiss national bank sets criteria for fintech companies' access to Swiss interbank clearing. https://www.snb.ch/en/mmr/reference/pre_20190111/source/ pre_20190111.en.pdf 
Tobin, J. (1987). A case for preserving regulatory distinctions. Challenge, 30(5), 10-17.

World Bank Group. (2017). The global findex database 2017. Available at: https://globalfindex.wor ldbank.org/

Yamaoka, H. (2019). The future of central banking. Accounting, Economics, and Law: A Convivium. Advance online publication. https://doi.org/10.1515/ael-2019-0003

Yanagawa, N., \& Yamaoka, H. (2019). Digital innovation, data revolution and central bank digital currency (Bank of Japan Working Paper No.19-E-2). Bank of Japan. https://www.boj.or.jp/en/ research/wps_rev/wps_2019/data/wp19e02.pdf

Open Access This chapter is licensed under the terms of the Creative Commons AttributionNonCommercial-NoDerivatives 4.0 International License (http://creativecommons.org/licenses/bync-nd/4.0/), which permits any noncommercial use, sharing, distribution and reproduction in any medium or format, as long as you give appropriate credit to the original author(s) and the source, provide a link to the Creative Commons license and indicate if you modified the licensed material. You do not have permission under this license to share adapted material derived from this chapter or parts of it.

The images or other third party material in this chapter are included in the chapter's Creative Commons license, unless indicated otherwise in a credit line to the material. If material is not included in the chapter's Creative Commons license and your intended use is not permitted by statutory regulation or exceeds the permitted use, you will need to obtain permission directly from the copyright holder.

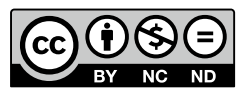

